\title{
Seedling competition between mountain rye, 'Hycrest' crested wheatgrass, and downy brome
}

\author{
ROBERT A. BUMAN, STEPHEN B. MONSEN, AND ROLLIN H. ABERNETHY
}

\section{Abatract}

For comparison of seedling growth competitive responses in a controlled environment, monocultures (intraspecific) and 2 species mixtures (interspecific) of mountain rye (Secale montanum), crested whentgrass (Agropyron cristatum $X$ desertorum 'Hycrest'), and downy brome (Bromus tectorum) were established. Seedling dry root and shoot weights, shoot area, and maximum root length were compared at 1, 2, 4, and 6 weeks of frowth in shoot roots boxes under a growth chamber environment $\left(16 \mathrm{hr} @ 14^{\circ} \mathrm{C}, 1,000\right.$

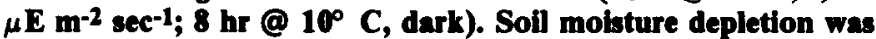
monitored gravimetrically. Dry root and shoot weight, shoot area, and root length of mountain rye was greater than that of both downy brome and Hyerest crested wheatgrass at every sampling period over the 6-week study when grown in two-species mixtures. No difference was obtained for these seedling growth characters between downy brome and Hycrest mixtures, except for $a 6.4 \mathrm{~cm}$ vs. $4.8 \mathrm{~cm}$ maximum root length at 1 week of growth. Similarly, in monoculture, mountain rye generally produced grenter seedling erowth than the other 2 species, although exceptions occurred for root weight, shoot area, and root length by 6 weeks of growth. Mountain rye depleted soll moisture in the growth boxes more rapidly and to a lower potential than the other 2 species. The results of this study indicate mountain rye provide vigorous competition as a seedlling.

Key Words: biological weed control, root frowth box Secale montanum Guss., Bromus tectorum L., Agropyron cristatum $\times$ desertorum

Downy brome (Bromus tectorum) is an introduced weedy, selfpollinated, winter annual (Hulbert 1955). Within the Intermountain region it has invaded and now occupies extensive areas throughout the salt desert, big sagebrush (Artemisia tridentata), pinyon juniper (Pinus/Juniperus) and mountain brush communities. Downy brome seed germinates in the fall or early spring over a wide range of moisture and temperature conditions (Thill et al. 1979) 1 . Seedlings quickly establish an extensive fibrous root system that will continue to grow over winter at soil temperatures of $3^{\circ} \mathrm{C}$ or above (Harris 1967). Young seedlings overwinter and resume vegetative growth early in the spring (Thill et al. 1984). Consequently, the plant is extremely competitive with both fall and spring germinating native plants. Downy brome matures in late spring and the mature, dry vegetation is highly flammable. While fire may reduce the soil seed reserves, fire also favors the reoccupation of this annual grass in subsequent years (Young et al. 1976). Chemical control approaches have had some success on rangelands (Eckert et al. 1974, Evans et al. 1967). An atrazine [6-chloro$N$ ethy- $N^{\prime}$ (1-methylethyl)-1,3,5-triazine-2,4-diamine-fallow system

Authors are former graduate assistant (currently graduate assistant, Department of Agronomy, Washington State University, Pullman); principal botanist, USDAForest Service Shrub Sciences Laboratory, Provo, Utah; and associate professor, Plant Science Department, the University of Wyoming, Laramie 82071 . This research was conducted by the senior author in partial fulfillment of the requirements for the M.S. degree in agronomy.

Journal Article 1523. Wyoming Agricultural Experiment Station.

The authors gratefully acknowledge provision of the Hycrest crested wheatgrass seed used in this study by Dr. Kay Asay (USDA-ARS; Logan, Utah) and the downy brome seed by Drs. Marshall Haferkamp and Dave Ganskopp (USDA-ARS; Burns, Ore.).

Manuscript accepted 20 August 1987.

'Buman, R.A., 1986. Seed germination and seedling interspecific competition of mountain rye (Secale montanum Guss.), Hycrest crested wheatgrass Agropyron cristatum $\times A$. desertorum Fisch.) and downy brome (Bromus tectorum L.) M.S. Thesis, University of Wyoming, Laramie, Wyoming. allowed establishment of perennial grasses and some shrubs when seeded the year following the fallow in a big sagebrush-downy brome community (Evans and Young 1977). The method has not seen widespread acceptance, presumably for economic and environmental reasons. A successful biological control approach would be more environmentally acceptable and could be more economical.

A short-lived, perennial grass species with extremely vigorous seedling growth that would germinate and establish simultaneously with downy brome might compete successfully such that downy brome seedlings would succumb. Soil seedbank reserves of brome would, after a few years, be depleted and longer-lived desired perennials could be established without additional downy brome control measures. We have begun an evaluation of 2 species in this regard. These 2 species, mountain rye (Secale montanum) and crested wheatgrass (Agropyron cristatum $\times$ desertorum 'Hycrest'), could potentially control downy brome through competitive interference and eventual exclusion. Hycrest crested wheatgrass has been suggested as a good competitor with downy brome because it produces a superior root system, has superior seedling vigor, produces $20 \%$ more seed, and is a larger and more robust plant than either of the 2 parent species. (Asay et al. 1985) Mountain rye is a highly polymorphic, short-lived perennial bunch grass that is native to the Middle Atlas mountains of Morocco, eastward in isolated pockets in the mountains of Turkey, Iran, and Iraq (Stutz 1972). Initially it was introduced in the United States in the 1930's as a forage plant, but has not gained wide acceptance because it is short-lived and seed has not been readily available (Plummer et al. 1968). Aldon et al. (1975) reported that mountain rye seedllings emerged as well in minespoil as in topsoil, suggesting its adaptation to harsh soil conditions. Monsen and Shaw (unpublished, USDA-FS report, Provo, Utah, 1985) observed that, when drill-seeded (11.2 kg ha $\left.{ }^{-1}\right)$ on a big sagebrush-bunch grass site receiving $325 \mathrm{~mm}$ annual precipitation that was infested with downy brome on the Boise National Forest, mountain rye established, persisted, and eventually eliminated annual brome. Over an approximate 50 -year period, mountain rye had occupied over 20 ha from the original seeded area of approximately 0.1 ha. Mountain rye has a longer vegetative growth period than downy brome and has greater forage production potential (unpublished observations of Monsen and Abernethy), although palatability is not known. If the competitive suppression of downy brome without prior control measures is to have promise, the competing species will likely need to germinate and grow concurrently with downy brome. The objective of this study was to compare seedling growth characteristics of mountain rye, Hycrest crested wheatgrass, and downy brome when grown under intra- and interspecific competition in a controlled environment. A companion study indicated the 3 species have similar germination temperature requirements (Buman and Abernethy 1988).

\section{Materials and Methods}

Mountain rye seed was collected by USDA-Forest Service personnel from a planting site near Boise, Idaho, in August 1984. Hycrest crested wheatgrass seed (1984 harvest) was obtained from USDA-ARS (Logan, Utah), in August, 1984. Downy brome seed was collected in June of 1984 from a rangeland site near Juniper Lake in southeast Oregon. The mountain rye seedlot was mechani- 
cally threshed and screened. Downy brome seed was deawned and screened, while Hycrest crested wheatgrass seed required no conditioning.

Seedling growth response to intraspecific (monoculture) and interspecific competition (combinations of 2 species) was determined using root observation growth boxes with inside dimension of 120 by 20 by $1 \mathrm{~cm}$. The boxes were filled with a potting mixture consisting of $71 \%$ sand, $18 \%$ clay and $11 \%$ silt with a pH of 7.5 , and brought to field capacity before planting. Monocultures of each species were established by planting 16 pure-live-seeds (PLS) equally spaced across the soil surface. The 2 species mixtures were established by alternately placing 8 PLS for each species across the soil surface. One centimeter of soil was used to cover the seed.

For germination and subsequent seedling growth, root boxes were placed in a plant growth chamber set on a $16-\mathrm{hr}$ day at $15^{\circ} \mathrm{C}$, chosen to stimulate spring or fall conditions. Fluorescent and incandescent lights provided $1000 \mu \mathrm{E} \mathrm{m}^{-2} \mathrm{sec}^{-1}$ at plant height. The root boxes were rerandomized in the growth chamber every 3 days. At 4,5 , and 6 weeks after planting, $10 \mathrm{ml}$ of supplemental water was added.

A randomized complete block experimental design with 4 replications over time was used. Eight boxes of each treatment were established for each replicate trial, thus providing 2 subsamples for each of the 3 different monocultures and each of the 3 mixtures for the sampling time periods of $1,2,4$ and 6 weeks.

At each sampling, soil samples were taken at depths of $15 \mathrm{~cm}, 30$ $\mathrm{cm}, 60 \mathrm{~cm}$, and $90 \mathrm{~cm}$ to determine soil moisture. The soil was oven dried and percent moisture was determined as described by Brower and $\mathrm{Zar}$ (1977). To calculate a soil matric water potential, samples were analyzed on a pressure plate apparatus at tensions of $0.03,0.5$, and 1.5 MPa and moisture percentages were determined (Richards 1965). Sample water potentials were then calculated from regression. Each root box was then disassembled and the soil washed from the roots by a fine mist of water. The maximum root length was determined by measuring the length of the longest root of each individual plant to the nearest $0.1 \mathrm{~cm}$. The dry root and shoot weights were measured by separating the shoots from the roots and drying at $60^{\circ} \mathrm{C}$ for $24 \mathrm{hr}$. The above-ground shoot area of the leaf and sheath was determined with a Decagon ${ }^{\oplus}$ leaf area meter. The per plant means for each growth parameter were calculated for the different sets of 8 subsamples and were used for multiple species comparisons. Mean separations were accomplished using either Bonferroni's multiple comparison procedure (Sachs 1982) or the LSD at an alpha of 0.05 .

Table 1. Dry root weights of mountain rye (Semo), downy brome (Brte), and 'Hycreat' created wheatgrass (Agerde) erown in monoculture or in mixtures of 2 species in plant growth chambers at 1,2,4, and 6 weeks after planting. Comparison groups were established for the purposes of means comparisons.

\begin{tabular}{|c|c|c|c|c|c|c|}
\hline \multirow[b]{2}{*}{ Comparison group } & \multirow[b]{2}{*}{ Competition type ${ }^{2}$} & \multirow[b]{2}{*}{ Species } & \multicolumn{4}{|c|}{ Dry root weight per plant } \\
\hline & & & Week 1 & Week 2 & Week 4 & Week 6 \\
\hline Comparison 1 & $\begin{array}{l}\text { Monoculture } \\
\text { Monoculture } \\
\text { Mixture } \\
\text { Mixture }\end{array}$ & $\begin{array}{l}\text { Semo } \\
\text { Brte } \\
\text { Semo } \\
\text { Brte }\end{array}$ & $\begin{array}{l}5.2 \mathrm{ab} \\
3.7 \mathrm{bc} \\
9.8 \mathrm{a} \\
2.6 \mathrm{c}\end{array}$ & $\begin{array}{r}18.9 \mathrm{a} \\
5.0 \mathrm{~b} \\
19.8 \mathrm{a} \\
5.1 \mathrm{~b}\end{array}$ & $\begin{array}{l}58.0 \mathrm{a} \\
29.0 \mathrm{~b} \\
84.4 \mathrm{a} \\
19.5 \mathrm{~b}\end{array}$ & $\begin{array}{c}84.7 \mathrm{ab} \\
57.0 \mathrm{bc} \\
149.6 \mathrm{a} \\
33.7 \mathrm{c}\end{array}$ \\
\hline Comparison 2 & $\begin{array}{l}\text { Monoculture } \\
\text { Monoculture } \\
\text { Mixture } \\
\text { Mixture }\end{array}$ & $\begin{array}{l}\text { Semo } \\
\text { Agcrde } \\
\text { Semo } \\
\text { Agcrde }\end{array}$ & $\begin{array}{r}5.2 \mathrm{a} \\
1.0 \mathrm{~b} \\
11.2 \mathrm{a} \\
1.1 \mathrm{~b}\end{array}$ & $\begin{array}{r}18.9 \mathrm{a} \\
5.7 \mathrm{~b} \\
16.5 \mathrm{a} \\
2.3 \mathrm{~b}\end{array}$ & $\begin{array}{r}58.0 \mathrm{a} \\
20.2 \mathrm{~b} \\
112.0 \mathrm{a} \\
18.0 \mathrm{~b}\end{array}$ & $\begin{array}{r}84.7 \mathrm{a} \\
44.8 \mathrm{~b} \\
120.3 \mathrm{a} \\
23.8 \mathrm{~b}\end{array}$ \\
\hline Comparison 3 & $\begin{array}{l}\text { Monoculture } \\
\text { Monoculture } \\
\text { Mixture } \\
\text { Mixture }\end{array}$ & $\begin{array}{l}\text { Brte } \\
\text { Agcrde } \\
\text { Brte } \\
\text { Agcrde }\end{array}$ & $\begin{array}{l}3.7 \mathrm{a} \\
1.0 \mathrm{a} \\
3.5 \mathrm{a} \\
2.2 \mathrm{a}\end{array}$ & $\begin{array}{l}5.0 \mathrm{a} \\
5.7 \mathrm{a} \\
5.0 \mathrm{a} \\
3.6 \mathrm{a}\end{array}$ & $\begin{array}{l}29.0 \mathrm{a} \\
20.2 \mathrm{a} \\
26.7 \mathrm{a} \\
16.4 \mathrm{a}\end{array}$ & $\begin{array}{l}57.0 \mathrm{ab} \\
81.9 \mathrm{a} \\
44.8 \mathrm{~b} \\
46.9 \mathrm{ab}\end{array}$ \\
\hline
\end{tabular}

'Means within the same time period and comparison followed by the same letter are not significantly different at the 0.05 proba bility level as determined by Bonferroni's multiple comparison procedure.

${ }^{2}$ Mixtures represent given species shown in combination with the other species in the comparison group.

Table 2. Dry shoot welghts of mountaln rye (Semo), downy brome (Brte), and 'Hycrest' created whentgrass (Agerde) grown in monocultures or mixturen of 2 species in plant growth chambers were eatablished at 1,2,4, and 6 weeks after planning. Comparison groups were eatabliahed for the purposes of means comparisons.

\begin{tabular}{|c|c|c|c|c|c|c|}
\hline \multirow[b]{2}{*}{ Comparison group } & \multirow[b]{2}{*}{ Competition type ${ }^{2}$} & \multirow[b]{2}{*}{ Species } & \multicolumn{4}{|c|}{ Dry root weight per plant } \\
\hline & & & Week 1 & Week 2 & Week 4 & Week 6 \\
\hline Comparison 1 & $\begin{array}{l}\text { Moncoulture } \\
\text { Monoculture } \\
\text { Mixture } \\
\text { Mixture }\end{array}$ & $\begin{array}{l}\text { Semo } \\
\text { Brte } \\
\text { Semo } \\
\text { Brte }\end{array}$ & $\begin{array}{l}5.3 \mathrm{a}^{1} \\
1.4 \mathrm{~b} \\
5.4 \mathrm{a} \\
1.6 \mathrm{~b}\end{array}$ & $\begin{array}{r}11.7 \mathrm{a} \\
2.9 \mathrm{~b} \\
22.3 \mathrm{a} \\
2.6 \mathrm{~b}\end{array}$ & $\begin{array}{l}39.8 \mathrm{a} \\
14.0 \mathrm{~b} \\
48.6 \mathrm{a} \\
11.6 \mathrm{~b}\end{array}$ & $\begin{array}{l}62.9 \mathrm{a} \\
28.4 \mathrm{~b} \\
95.6 \mathrm{a} \\
17.2 \mathrm{~b}\end{array}$ \\
\hline Comparison & $\begin{array}{l}\text { Monoculture } \\
\text { Monculture } \\
\text { Mixture } \\
\text { Mixture }\end{array}$ & $\begin{array}{l}\text { Semo } \\
\text { Agcrde } \\
\text { Semo } \\
\text { Agerde }\end{array}$ & $\begin{array}{l}5.3 \mathrm{a} \\
0.8 \mathrm{~b} \\
5.3 \mathrm{a} \\
0.8 \mathrm{~b}\end{array}$ & $\begin{array}{r}11.7 \mathrm{a} \\
2.4 \mathrm{~b} \\
10.5 \mathrm{a} \\
2.0 \mathrm{~b}\end{array}$ & $\begin{array}{l}39.9 \mathrm{a} \\
11.7 \mathrm{~b} \\
51.5 \mathrm{a} \\
8.1 \mathrm{~b}\end{array}$ & $\begin{array}{l}62.9 \mathrm{a} \\
23.8 \mathrm{~b} \\
75.5 \mathrm{a} \\
14.0 \mathrm{~b}\end{array}$ \\
\hline Comparison 3 & $\begin{array}{l}\text { Monoculture } \\
\text { Monoculture } \\
\text { Mixture } \\
\text { Mixture }\end{array}$ & $\begin{array}{l}\text { Brte } \\
\text { Agcrde } \\
\text { Brte } \\
\text { Agcrde }\end{array}$ & $\begin{array}{l}1.4 \mathrm{a} \\
0.8 \mathrm{a} \\
1.6 \mathrm{a} \\
1.3 \mathrm{a}\end{array}$ & $\begin{array}{l}2.9 \mathrm{a} \\
2.4 \mathrm{a} \\
2.6 \mathrm{a} \\
2.3 \mathrm{a}\end{array}$ & $\begin{array}{l}14.0 \mathrm{a} \\
11.7 \mathrm{a} \\
20.5 \mathrm{a} \\
10.6 \mathrm{a}\end{array}$ & $\begin{array}{l}28.4 \mathrm{a} \\
23.8 \mathrm{a} \\
42.2 \mathrm{a} \\
29.7 \mathrm{a}\end{array}$ \\
\hline
\end{tabular}

'Means within the same time period and comparison followed by the same letter are not significantly different at a 0.05 probability level as determined by Bonferroni's multiple comparison procedure.

${ }^{2}$ Mixtures represent given species grown in combination with the other species in the comparison group. 


\section{Results}

Comparisons of greatest interest were between mountain rye and downy brome and Hycrest crested wheatgrass and downy brome, when competing as mixtures. The effect of mixtures was also contrasted with growth when competing as monocultures, for all 3 species.

Dry root weight of mountain rye was significantly $(P \leq .05)$ greater than that of downy brome and Hycrest crested wheatgrass when grown in 2 species mixtures at each sampling throughout the 6-week growth period (Table 1). Mountain rye produced significantly greater dry weight than downy brome at 2 and 4 week samplings when grown in monoculture. Mountain rye in monoculture produced greater root weight than Hycrest crested wheatgrass in monoculture over the entire 6-week period. No difference in dry root weight for monoculture or mixture comparisons of Hycrest crested wheatgrass and downy brome occurred.

Dry shoot weight of mountain rye was significantly $(P \leq .05)$ greater than that of downy brome and Hycrest crested wheatgrass when grown in 2 species mixtures at each sampling throughout the 6-week period (Table 2). Mountain rye also produced greater dry shoot weight than either downy brome brome or Hycrest crested wheatgrass and downy brome occurred.
Dry shoot weight of mountain rye was significantly $(P \leq .05)$ greater than that of downy brome and Hycrest crested wheatgrass when grown in 2 species mixtures at each sampling throughout the 6 week period (Table 2). Mountain rye also produced greater dry shoot weight than either downy brome or Hycrest crested wheatgrass at each sampling when grown in monoculture.

Shoot area of mountain rye was greater than that of both downy brome and Hycrest crested wheatgrass, when grown in mixtures, at each sampling throughout the 6-week growth period (Table 3). While no differences in shoot area were apparent between downy brome and Hycrest crested wheatgrass mixtures, mountain rye also produced significantly $(P \leq .05)$ greater shoot area than downy brome at 1,2 , and 4 week sampling periods when grown in monoculture, but by 6 weeks, no difference was obtained. Mountain rye in monoculture produced greater shoot area than Hycrest crested wheatgrass in monoculture at each of the sampling dates.

Maximum root length of mountain rye was significantly greater than that of Hycrest crested wheatgrass and downy brome when grown in mixtures (Table 4); the same relationship was apparent, although not always significant, in monoculture treatments. When comparing the root length of downy brome to Hycrest crested wheatgrass in monoculture or mixtures, there was no significant

Table 3. Shoot area of mountain rye (Semo), downy brome (Brte), and 'Hycrest' crested wheatgrass (Agerde) grown in monoculture or mixtures of two species in plant growth chambers were sampled at 1,2,4, and 6 weeks after planting. Comparison groups were eatabliahed for the purpose of means comparison.

\begin{tabular}{|c|c|c|c|c|c|c|}
\hline \multirow[b]{2}{*}{ Comparison group } & \multirow[b]{2}{*}{ Competition type ${ }^{2}$} & \multirow[b]{2}{*}{ Species } & \multicolumn{4}{|c|}{ Shoot Area per plant } \\
\hline & & & Week 1 & Week 2 & Week 4 & Week 6 \\
\hline Comparison 1 & $\begin{array}{l}\text { Monoculture } \\
\text { Monoculture } \\
\text { Mixture } \\
\text { Mixture }\end{array}$ & $\begin{array}{l}\text { Semo } \\
\text { Brte } \\
\text { Semo } \\
\text { Brte }\end{array}$ & $\begin{array}{l}0.79 \mathrm{a}^{1} \\
0.14 \mathrm{~b} \\
0.82 \mathrm{a} \\
0.20 \mathrm{~b}\end{array}$ & $\begin{array}{l}1.92 \mathrm{a} \\
0.63 \mathrm{~b} \\
1.88 \mathrm{a} \\
0.63 \mathrm{~b}\end{array}$ & $\begin{array}{l}4.83 \mathrm{a} \\
2.49 \mathrm{~b} \\
6.08 \mathrm{a} \\
1.99 \mathrm{~b}\end{array}$ & $\begin{array}{l}6.11 \mathrm{ab} \\
4.03 \mathrm{bc} \\
9.88 \mathrm{a} \\
2.45 \mathrm{c}\end{array}$ \\
\hline Comparison 2 & $\begin{array}{l}\text { Monoculture } \\
\text { Monoculture } \\
\text { Mixture } \\
\text { Mixture }\end{array}$ & $\begin{array}{l}\text { Semo } \\
\text { Agcrde } \\
\text { Semo } \\
\text { Agcrde }\end{array}$ & $\begin{array}{l}0.79 a \\
0.05 b \\
0.87 a \\
0.09 b\end{array}$ & $\begin{array}{l}1.92 \mathrm{a} \\
0.37 \mathrm{~b} \\
1.81 \mathrm{a} \\
0.36 \mathrm{~b}\end{array}$ & $\begin{array}{l}4.83 \mathrm{a} \\
1.85 \mathrm{~b} \\
7.66 \mathrm{a} \\
0.99 \mathrm{~b}\end{array}$ & $\begin{array}{l}6.11 \mathrm{a} \\
2.47 \mathrm{~b} \\
8.52 \mathrm{a} \\
1.38 \mathrm{~b}\end{array}$ \\
\hline Comparison 3 & $\begin{array}{l}\text { Monoculture } \\
\text { Monoculture } \\
\text { Mixture } \\
\text { Mixture }\end{array}$ & $\begin{array}{l}\text { Brte } \\
\text { Agcrde } \\
\text { Brte } \\
\text { Agcrde }\end{array}$ & $\begin{array}{l}0.14 \mathrm{a} \\
0.05 \mathrm{~b} \\
0.14 \mathrm{a} \\
0.10 \mathrm{ab}\end{array}$ & $\begin{array}{l}0.63 \mathrm{a} \\
0.37 \mathrm{a} \\
0.59 \mathrm{a} \\
0.44 \mathrm{a}\end{array}$ & $\begin{array}{l}2.49 \mathrm{a} \\
1.58 \mathrm{a} \\
2.46 \mathrm{a} \\
1.38 \mathrm{a}\end{array}$ & $\begin{array}{l}4.03 \mathrm{ab} \\
2.74 \mathrm{~b} \\
5.86 \mathrm{a} \\
3.24 \mathrm{ab}\end{array}$ \\
\hline
\end{tabular}

'Means within the same time period and comparison followed by the same letter are not significantly different at a 0.05 probability level as determined by Bonferroni's multiple comparison procedure.

${ }^{2}$ Mixtures represent given species grown in combination with the other species in the comparison group.

Table 4. Maximum root length of mountain rye (Semo), downy brome (Brte), and 'Hycrest' crested whentgrass (Agerde) grown in monoculture or mixtures of 2 species were sampled at 1, 2, 4, and 6 weeks after planting. Comparison groups were established for the purpose of means comparisons.

\begin{tabular}{|c|c|c|c|c|c|c|}
\hline \multirow[b]{2}{*}{ Comparison } & \multirow[b]{2}{*}{ Competition type ${ }^{2}$} & \multirow[b]{2}{*}{ Species } & \multicolumn{4}{|c|}{ Maximum Root Length per plant } \\
\hline & & & Week 1 & Week 2 & Week 4 & Week 6 \\
\hline Comparison 1 & $\begin{array}{l}\text { Monoculture } \\
\text { Monoculture } \\
\text { Mixture } \\
\text { Mixture }\end{array}$ & $\begin{array}{l}\text { Semo } \\
\text { Brte } \\
\text { Semo } \\
\text { Brte }\end{array}$ & $\begin{array}{l}8.5 \mathrm{a}^{1} \\
6.6 \mathrm{ab} \\
8.1 \mathrm{a} \\
5.5 \mathrm{~b}\end{array}$ & $\begin{array}{l}18.3 \mathrm{a} \\
11.5 \mathrm{~b} \\
18.0 \mathrm{a} \\
12.4 \mathrm{~b}\end{array}$ & $\begin{array}{l}42.2 \mathrm{ab} \\
34.0 \mathrm{bc} \\
50.7 \mathrm{a} \\
29.7 \mathrm{c}\end{array}$ & $\begin{array}{l}49.4 \mathrm{a} \\
43.7 \mathrm{ab} \\
55.1 \mathrm{a} \\
25.9 \mathrm{~b}\end{array}$ \\
\hline Comparison 2 & $\begin{array}{l}\text { Monoculture } \\
\text { Monoculture } \\
\text { Mixture } \\
\text { Mixture }\end{array}$ & $\begin{array}{l}\text { Semo } \\
\text { Agcrde } \\
\text { Semo } \\
\text { Agcrde }\end{array}$ & $\begin{array}{l}8.5 \mathrm{a} \\
3.8 \mathrm{~b} \\
8.4 \mathrm{a} \\
3.6 \mathrm{~b}\end{array}$ & $\begin{array}{r}18.3 \mathrm{a} \\
16.3 \mathrm{a} \\
10.0 \mathrm{~b} \\
9.9 \mathrm{~b}\end{array}$ & $\begin{array}{l}42.2 \mathrm{a} \\
27.6 \mathrm{~b} \\
49.8 \mathrm{a} \\
24.6 \mathrm{~b}\end{array}$ & $\begin{array}{l}49.4 \mathrm{ab} \\
41.7 \mathrm{bc} \\
60.5 \mathrm{a} \\
30.5 \mathrm{c}\end{array}$ \\
\hline Comparison 3 & $\begin{array}{l}\text { Monoculture } \\
\text { Monoculture } \\
\text { Mixture } \\
\text { Mixture }\end{array}$ & $\begin{array}{l}\text { Brte } \\
\text { Agcrde } \\
\text { Brte } \\
\text { Agcrde }\end{array}$ & $\begin{array}{l}6.6 \mathrm{a} \\
3.8 \mathrm{~b} \\
6.4 \mathrm{a} \\
4.8 \mathrm{~b}\end{array}$ & $\begin{array}{l}11.5 \mathrm{ab} \\
16.3 \mathrm{a} \\
12.2 \mathrm{ab} \\
10.2 \mathrm{~b}\end{array}$ & $\begin{array}{l}34.0 \mathrm{a} \\
27.6 \mathrm{a} \\
32.3 \mathrm{a} \\
28.9 \mathrm{a}\end{array}$ & $\begin{array}{l}43.7 \mathrm{a} \\
41.2 \mathrm{a} \\
38.7 \mathrm{a} \\
38.2 \mathrm{a}\end{array}$ \\
\hline
\end{tabular}

'Means within the same time period and comparison followed by the same letter are not significantly different at a 0.05 probability level as determined by Bonferroni's multiple comparison procedure.

${ }^{2}$ Mixtures represent given species grown in combination with the other species in the comparison group. 


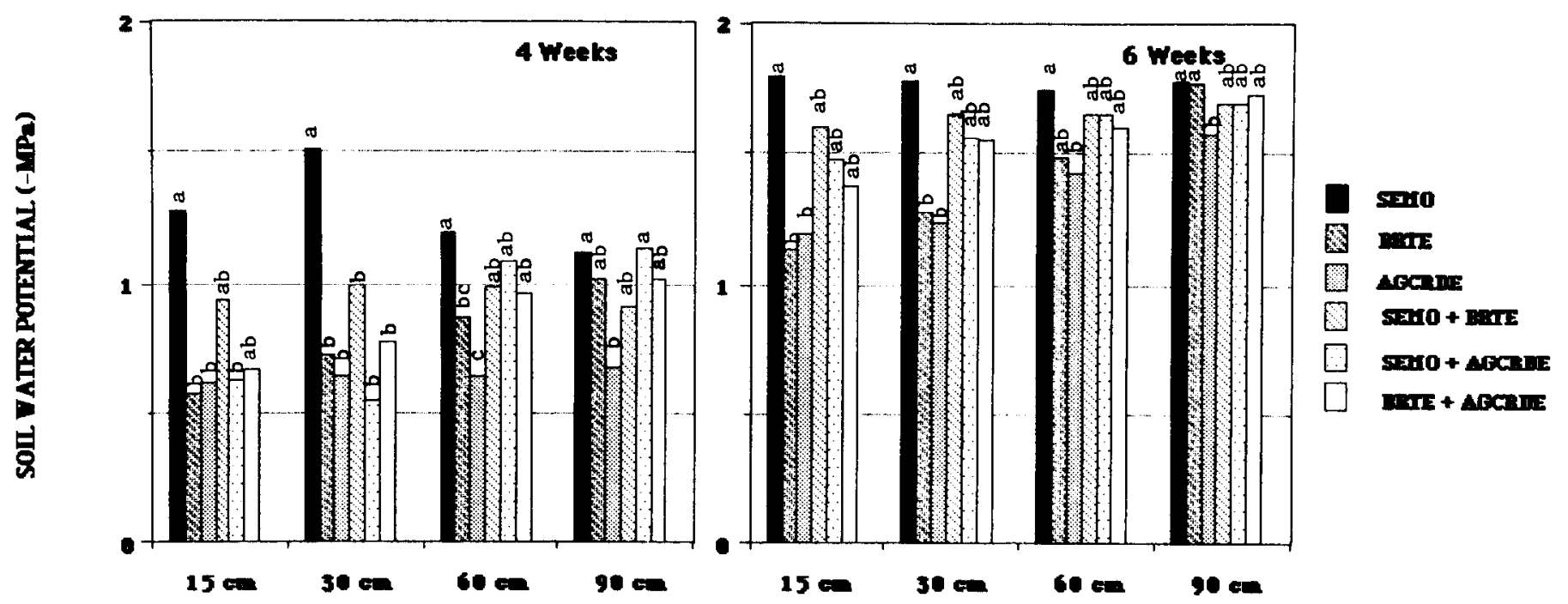

SOIL. DEPTB

Fig. 1. Calculated soil matric potential and 4 and 6 weeks after planting in root growth boxes at 4 depths. Monoculture and mixed culture plantings of mountain rye (Semo), downy brome (Brte) and Hycrest crested wheatgrass (Agcrde) are compared. Bars within a soil depth of 1 sampling time capped by the same letter are not significantly different at the 0.05 level of alpha when compared by the L.S.D.

difference $(P \leq .05)$ after the second week of sampling.

No significant differences $(P \leq .05)$ in dry root weight, dry shoot weight, shoot area, and root length were apparent when each species in monoculture was compared to those of the same species grown in a 2-species mixture, except for 1 case: Hycrest crested wheatgrass values for root length at 2 weeks of growth. Despite this lack of difference, a pattern developed (Tables 1 to 4). Mountain rye, by 4 weeks after planting, consistently had greater root and shoot dry weight, shoot area, and root lengths when grown in a mixture with the other 2 species than when it was grown in monoculture. When either downy brome or Hycrest crested wheatgrass was grown in combination with mountain rye, they had lower root and shoot dry weight, shoot area, and root length values than when grown as monocultures.

Mountain rye monocultures depleted the soil moisture in the growth boxes more rapidly and to a lower water potential than did the other monoculture treatments at 4 and 6 weeks of growth, suggesting its greater shoot area provided more transpiring surface area (Fig. 1). Hycrest crested wheatgrass tended to deplete soil moisture the least of any treatment in both monoculture and mixtures. The soil moisture data did not reveal any other definite trends. Soil moisture measurements at the $15 \mathrm{~cm}$ depth at 4 and 6 weeks were influenced by the addition of supplemental water to the soil surface. Six-week data reflected a general drying of the soil due to evaporative loss through the root growth boxes, particularly at the 60 and $90 \mathrm{~cm}$ depths, although the greater water utilization of mountain rye was still apparent.

\section{Discussion}

Buman ${ }^{1}$ has shown that temperature requirements for germination of mountain rye and Hycrest crested wheatgrass are similar to those of downy brome, suggesting that either species would be capable of fall and / or early spring germination corresponding with that of downy brome. The results of the present study demonstrated that seedling growth of mountain rye through 6 weeks exceeded that of both Hycrest crested wheatgrass and downy brome, particulary when grown in competition. Based on earlier work (Bookman and Mack 1982; Harris 1977) and trends obtained in this study, root growth and development of downy brome may be inhibited by the competition provided from an established grass or a more vigorously developing seedling.
Crested wheatgrass (Agropyron desertorum) has been found to compete with downy brome more effectively than bluebunch wheatgrass (Agropyron spicatum $)^{2}$ because the root elongation rate of crested wheatgrass was greater than that of bluebunch wheatgrass at low soil temperature, allowing it to access soil moisture and nutrients similarly to that of downy brome (Harris 1967, Harris and Wilson 1970). This subsequently limits the ability of downy brome to obtain water and nutrients and results in suppression of growth. Soil moisture depletion by mountain rye would further limit downy brome seedling growth. Harris (1967) concluded from his studies of bluebunch wheatgrass and downy brome, that aboveground competition for light was not an important factor in the seedling stage or at any age. Conversely, Bookman and Mack (1983) found that downy brome growing beneath an established canopy of bluegrass (Poa pratensis) displayed larger biomass and higher survival when exposed to supplemental light. They suggested that shading of downy brome may limit photosynthate allocation for root growth and thereby reduce the rooting volume. Therefore, the shoot area of mountain rye, greater than that of the other 2 species in our study, may also have contributed to competitive suppression through shading of downy brome. This greater shoot area also likely plays a role in the greater soil moisture depletion exhibited by mountain rye seedlings.

Hycrest crested wheatgrass, while not demonstrating the seedling vigor of mountain rye, was equal to downy brome in the seedling growth characters measured in this study. Hironaka (1961) conducted a field study aimed at understanding the replacement of downy brome by even less desirable medusahead (Elymus caputmedusae=Taeiatherum caputmedusae) in parts of Idaho and other Pacific Northwest states. Root elongation was similar for both species. He concluded the successful competition by medusahead was dependent on soil moisture availability for completion of its life cycle, thereby providing a seed source. Under this premise, a species need only be equal to downy brome in seedling vigor to successfully compete. An aggressive perennial species such as crested wheatgrass may also successfully compete with downy brome seedlings following the year of establishment, if it can adequately compete during the seedling year to survive. It

${ }^{2}$ Agropyron spicatum has recently been reclassified as Pseudoroegneria spicata (Pursh) A. Love; Dewey, D.R. 1984. The genomic system of classification as a guide to intergeneric hybridization with the perennial Triticeae. p. 209-279. In: J.P. Gustafson (ed.) Gene manipulation in plant improvement. Plenum Pub., N.Y., N.Y. 
may be possible to establish mountain rye and/or Hycrest crested wheatgrass at low seeding rates, and with aggressive growth habit eventually suppress annual bromes. The potential for reduced tillage planting techniques, i.e., interseeding, which are less costly may also be effective. The concept of utilizing a vigorous perennial that would establish simultaneously and compete with seedling downy brome as a method for its control was initially proposed by Evans et al. (1970).

The potential for mountain rye to successfully replace downy brome under field environments remains to be answered. The present study suggests potential; however it was conducted under only 1 set of environmental conditions. Harris and Wilson (1970) reported downy brome root elongation continued at soil temperatures of $3^{\circ} \mathrm{C}$, lower than the soil temperature obtained in this study. In addition, downy brome density can play a role in the ability of other species to successfully compete with it. Evans (1961) found that downy brome densities of 64 and 256 plants per square foot severely depressed growth of crested wheatgrass seedlings in a greenhouse study conducted at temperatures similar to those used in this study. Both species were seeded at the same time. The crested wheatgrass available at the time of Evans' study would likely be less vigorous as a seedling than Hycrest crested wheatgrass (Asay 1985) or mountain rye.

An on-going field study will assess the ability of mountain rye to suppress downy brome for a period of time sufficient to deplete the downy brome soil seedbank. The longevity of mountain rye and the potential for its replacement by other desired perennial grass species will be monitored. Several accessions of mountain rye are available that differ in longevity and other growth characteristics. The possibility of mountain rye itself having weedy characteristics must be assessed before widespread use of the species can be considered.

\section{Literature Cited}

Aldon, E.F., H.W. Sprinfield, and G. Garcia. 1975. Can soil amendments aid revegetation of New Mexico coal mine spoils? USDA-FS RM-292.

Asay, K.H., D.R. Dewey, F.B. Gomm, D.A. Johnson, and J.R. Carlaon. 1985. Registration of Hycrest crested wheatgrass. Crop Sci. 25:368-369.

Bookman, P.A., and R.N. Mack. 1982. Root interactions between Bromus tectorum and Poa pratensis: a 3 dimensional analysis. Ecology 63:640-646.

Bookman, P.A., and R.N. Mack. 1983. Competition between Bromus tectorum L. and Poa pratensis L: the role of light. Oecologia 57:406-411.
Brower, J.E., and J.H. Zar. 1977. Field and laboratory methods for general ecology. Wm. C. Brown Co., Publishers. Dubuque, Iowa.

Buman, R.A., and R.H. Abernethy. 1988. Temperature requirements for mountain rye, hycrest crested wheatgrass, and downy brome germination. J. Range Manage 41:35-39.

Eckert, R.E., Jr., J.E. Asher, M.D. Christensen, and R.A. Evans. 1974. Evaluation of the atrazine-fallow technique for weed control and seeding establishment. J. Range Manage. 27:288-292.

Evans, R.A. 1961. Effects of different densities of downy brome (Bromus rectorum) on growth and survival of crested wheatgrass (Agropyron desertorum) in the greenhouse. Weeds 9:216-223.

Evans, R.A., R.E. Eckert, Jr., and B.L. Kay. 1967. Wheatgrass establishment with paraquat and tillage on downy brome ranges. Weed Sci. 15:50-55.

Evans, R.A., H.R. Holbo, R.E. Eckert, Jr., and J.A. Young. 1970. Functional environment of downy brome communities in relation to weed control and revegetation. Weed Sci. 18:154-162.

Evans, R.A., and J.A. Young. 1977. Weed control-revegetation systems for big sagebrush-downy brome rangelands. J. Range Manage. 30:331-336.

Harris, G.A. 1967. Some competitive relationships between Agropyron spicatum and Bromus tectorum. Ecol. Monogr. 37:89-111.

Harris, G.A. 1977. Root phenology as a factor of competition among grass seedlings. J. Range Manage. 30:172-177.

Harris, Grant A., and A.M. Wilson. 1970. Competition for moisture among seedlings of annual and perennial grasses as influenced by root elongation at low temperature. Ecology 51:530-534.

Hironaka, M. 1961. The relative rate of root development of cheatgrass and medusahead. J. Range Manage. 14:263-267.

Hulbert, L.C. 1955. Ecological studies of Bromus tectorum and other annual brome grasses. Ecol. Monogr. 25:181-213.

Plummer, A.P., D.R. Chriatensen, and S.B. Monsen. 1968. Restoring big-game range in Utah. Utah Division of Fish and Game Publ. No. 68-3. pp. 136-137.

Richards, L.A. 1965. Physical condition of water in soil. In (C.A. Black, ed.) Agronomy No. 9, Part 1. Methods of Soil Analysis. Amer. Soc. Agron. Madison, Wis.

Sachs, L. 1982. Applied statistics: A handbook of techniques. pp. 264-270. Springer-Verlag. New York.

Stutz, H.C. 1972. On the origin of cultivated rye. Amer. J. Botany 59:59-70.

Thill, D.C., K.G. Beck, and R.H. Callhan. 1984. The biology of downy brome (Bromus tectorum). Weed Sci. 32:7-12.

Thill, D.C., R.D. Schirman, and A.P. Appleby. 1979. Influence of soil moisture, temperature, and compaction on the germination of downy brome (Bromus tectorum). Weed Sci. 27:625-630.

Young, J.A., R.A. Evans, and R.R. Weaver. 1976. Estimating potential downy brome competition after wildfires. J. Range Manage. 29:322-325.

\section{SRM Election Results}

The Elections Committee Chairman, Craig Whittekiend, along with several other Colorado Section members, counted the ballots for new officers on Monday December 7, 1987, at the Society for Range Management headquarters. Elected officers are:

Second Vice-President-Rex Cleary

Directors (1988-1990) - Kendall Johnson and Ed Nelson

Directors Johnson and Nelson will replace retiring Directors Cleary and Ross in Feburary 1988.

Ballots and tally sheets are retained in the Denver office for one year for review. Approximately $30 \%$ of the membership voted. 